\title{
Platelet aggregation responses in type 2 diabetic patients
}

\author{
Fatma Mutlu Kukul Güven ${ }^{1 *}$, Abdülkerim Yilmaz ${ }^{1}$, Hüseyin Aydin², Ilhan Korkmaz ${ }^{1}$, \\ Sevki Hakan Eren ${ }^{1}$
}

${ }^{1}$ Emergency Medicine Deparment, School of Medicine, Cumhuriyet University, Sivas, Turkey;

*Corresponding Author: fmkg@hotmail.com

${ }^{2}$ Biochemistry Lab, School of Medicine, Cumhuriyet University, Sivas, Turkey; haydin@

Received 12 February 2010; revised 12 March 2010; accepted 14 March 2010.

\begin{abstract}
Diabetes mellitus (DM) is associated with platelet dysfunction. In diabetic patients, alterations in platelet functions, especially increased platelet agregation, have been suggested to cause increasing in cardiovascular morbidity and mortality or in accelaretion of athersclerotic process. In this study, we aimed to investigate the platelet aggregation response alterations and the effects of DM duration, $\mathrm{HbA}_{1 \mathrm{c}}$, treatment options among the patients with Type 2 DM. Fortyfive patients (case group; 21 male, 24 female) with Type 2 DM and forty-eight healthy individuals (control group; 22 male, 26 female) were included in this study. Platelet aggregation was determinated with Chorono-log 500 (USA) named device by using Chorono-log/ADP, Chorono-log/ collagen and Chorono-log/epinephrine kits. ADP-induced platelet aggregation was significantly higher in the case group compared with control group $(p<0.05)$. Epinephrine induced platelet aggregation were significant in negatively correlation with the diabetes duration $(P<$ 0.05). Platelet aggregation responses did not differ according to their treatment type (sulphonylurea or insulin) was statistically insignificiant among the case groups $(p>0.05)$. In conclusion, our findings supported that type 2 diabetes may interfere with platelet functions without any relationship age, gender, the treatment types and the regulation levels. These findings supports that existence potential new factors or mechanism affecting platelet agregation. The subject requires more detailed studies in the future.
\end{abstract}

Keywords: Platelet Aggregation; Diabetes;
Insulin; HbA1c

\section{INTRODUCTION}

Evidencies for abnormal platelet functions in diabetes mellitus (DM) have been shown as: altered platelet functions $[1,2]$, increased aggregation of platelet that leads to acceleration of atherogenesis [1], abnormal platelet activation suggested to cause micro or macro angiopaties [2-4] and platelet hyperactivities [5,6].

The aim of this study was to investigate the platelet aggregation response alterations and the effects of DM duration, $\mathrm{HbA}_{1 \mathrm{c}}$, treatment options among the patients with Type $2 \mathrm{DM}$.

\section{METHOD}

This study was performed in Cumhuriyet University Medicine Faculty Emergency Department between January-December 2003.

Study population: Forty-five patients (case group; 21 male, 24 female) with Type 2 DM diagnosis and fortyeight healthy individuals (control group; 22 male, 26 female) were included in this study. Case and controls had not any other systemic disease except type 2 DM. Neither of the patient of case group was diagnosed as type $1 \mathrm{DM}$. nor of the participitants had a treatment history by a drug that interferes platelet aggregation.

Blood sampling: A fasting state venous blood sample were taken in vaccuated tubes for all participitans and send to biochemistry laboratory within 30 minutes to measure blood glucose and $\mathrm{HbA}_{1 \mathrm{c}}$. For platelet aggregation responses measurement venous blood samples were send to hematology laboratory within 30 minutes in $0.2 \mathrm{ml}$ citrates containing tubes.

Study procedure: Blood glucose and $\mathrm{HbAlc}$ were studied by standart laboratory methods. Platelet aggre- 
gation was determinated with Chorono-log 500 (USA) named device by using Chorono-log/ADP, Chorono-log/ collegen and Chorono-log/epinephrine kits.

Statistical analysis: Data analysis were performed on SPSS (Ver 13.0) software by using chi-square, studen-t, Mann-Whitney $\mathrm{U}$ tests and correlation analysis.

\section{RESULTS}

The mean age was $58.68 \pm 1.37$ years in the case group and $53.72 \pm 2.10$ years in the control group. When case and control groups were statistically compared upon to their mean age and gender the difference was insignificant $(\mathrm{P}>0.05)$ (Table 1). The mean glucose levels in the case and control groups were as $224.44 \pm 15.95 \mathrm{mg} / \mathrm{dl}$ and $99.16 \pm 11.84 \mathrm{mg} / \mathrm{dl}$. The mean HbAlc level in the case group was $9.59 \pm 0.38 \mathrm{mg} / \mathrm{dl}$. The mean duration of diabetes in the case group was $8.06 \pm 0.83$ years. Sulfonylurea drugs were used in $44.45 \%$ [20] patient and insulin was preferred in 55.5\% [25] patient for treatment.

Platelet aggregation responses induced with epinephrine, collagen and adenosine diphosphate (ADP) were measured and mean results were recorded as percentage $(\%)$ for both groups. The difference between the case and control groups were statistically insignificiant in terms of platelet aggregation responses induced with epinephrine and collagen $(\mathrm{p}>0.05)$. Whereas; ADP-induced platelet aggregation was significantly higher in the case group compared with control group. (Table 2).

Platelet aggregation responses induced with all three activators were not in correlation with the ages in the both groups. (Table 3).

Platelet aggregation responses induced with all three activators were in negatively correlation with the diabetes duration. However, the correlation were significant for only epinephrine $(\mathrm{P}<0.05)$. (Table 4).

When the platelet aggregation responses induced with three activators in the case groups were compared with HbA1c levels and the difference were not significant in statistical analysis $(\mathrm{p}>0.05)$. (Table 5).

Platelet aggregation responses did not differ according to their treatment type (sulphonylurea or insulin) and statistically it was insignificiant among the case groups $(p>0.05)$. (Table 6).

\section{DISCUSSION}

Platelets functions are significant to understanding the pathophysiology of vascular disease in diabetes. The role of hyperglycemia is not clear in platelet hyperactivity in diabetic patients [7].

Platelet dysfunction may develop before vessel wall damage in diabetes $[8,9]$. Platelet dysfunction in diabetes, including altered adhesion and aggregation, is hypersensitivity to agonists [10].

Patient with type $2 \mathrm{DM}$ had altered platelet functions and increased platelet aggregation responses with agonists $[11,12]$.

Table 1. Epidemiological and laboratory properties of case and control groups.

\begin{tabular}{lccc}
\hline & $\begin{array}{c}\text { Cases } \\
\bar{x} \pm \mathrm{S}_{\mathrm{e}}\end{array}$ & $\begin{array}{c}\text { Controls } \\
\bar{x} \pm \mathrm{S}_{\mathrm{e}}\end{array}$ & $\mathbf{P}$ \\
\hline $\mathrm{n}(\mathrm{f} / \mathrm{m})$ & $45(24 / 21)$ & $48(26 / 22)$ & $\mathrm{p}>0.05$ \\
Mean Age (year) & $58.68 \pm 1.37$ & $53.72 \pm 2.10$ & $\mathrm{p}>0.05$ \\
$\begin{array}{l}\text { Mean time of DM } \\
\text { (year) }\end{array}$ & $8.06 \pm 0.83$ & - & - \\
$\begin{array}{l}\text { Treatment (OAD/ins) } \\
\text { HbA1c(mg/dL) }\end{array}$ & $20 / 25$ & - & - \\
$\begin{array}{l}\text { Blood glucose } \\
\text { (mg/dL) }\end{array}$ & $224.44 \pm 15.95$ & $99.16 \pm 11.84$ & $\mathrm{P}<0.05$ \\
\hline
\end{tabular}

Table 2. Comparison of platelet aggregation responses in the case and control groups.

\begin{tabular}{lccc}
\hline Groups & $\begin{array}{c}\text { Epinephrine } \\
\text { induced platelet } \\
\text { aggregation (\%) }\end{array}$ & $\begin{array}{c}\text { Collagen induced } \\
\text { platelet } \\
\text { aggregation (\%) }\end{array}$ & $\begin{array}{c}\text { ADP induced } \\
\text { platelet } \\
\text { aggregation (\%) }\end{array}$ \\
\hline Case & $45.75 \pm 2.26$ & $54.82 \pm 2.76$ & $74.91 \pm 3.61$ \\
Control & $42.43 \pm 2.78$ & $51.39 \pm 2.00$ & $55.72 \pm 1.77$ \\
p & $\mathrm{t}=0.91 \mathrm{p}>0.05$ & $\mathrm{t}=1.01 \mathrm{p}>0.05$ & $\mathrm{t}=4.85 \mathrm{p}<0.05$ \\
\hline
\end{tabular}

Table 3. Correlation between the age and platelet aggregation in the case and control groups.

\begin{tabular}{cccc}
\hline Age & $\begin{array}{c}\text { Epinephrine } \\
(\mathbf{\%})\end{array}$ & $\begin{array}{c}\text { collagen } \\
\mathbf{( \% )}\end{array}$ & ADP (\%) \\
\hline Case & $\mathrm{r}=0.11$ & $\mathrm{r}=0.03$ & $\mathrm{r}=0.13$ \\
$58.68 \pm 1.37$ & $\mathrm{p}>0.05$ & $\mathrm{p}>0.05$ & $\mathrm{p}>0.05$ \\
& & & \\
Control & $\mathrm{r}=-0.11$ & $\mathrm{r}=-0.09$ & $\mathrm{r}=-0.07$ \\
$53.72 \pm 2.10$ & $\mathrm{p}>0.05$ & $\mathrm{p}>0.05$ & $\mathrm{p}>0.05$ \\
\hline
\end{tabular}

Table 4. Correlation between Diabetes duration and platelet aggregation in the case group.

\begin{tabular}{cccc}
\hline & $\begin{array}{c}\text { Epinephrine } \\
\text { (\%) }\end{array}$ & Collagen (\%) & ADP (\%) \\
\cline { 2 - 4 } $\begin{array}{c}\text { Diabetes } \\
\text { duration }\end{array}$ & $\mathrm{r}=-0.31$ & $\mathrm{r}=-0.23$ & $\mathrm{r}=0.11$ \\
& $\mathrm{p}<0.05$ & $\mathrm{p}>0.05$ & $\mathrm{p}>0.05$ \\
\hline
\end{tabular}


Table 5. Correlation between $\mathrm{HbA} 1 \mathrm{c}$ levels and the platelet aggregation in the case group.

\begin{tabular}{|c|c|c|c|c|c|}
\hline \multirow{2}{*}{ Case Group } & \multicolumn{4}{|c|}{$\mathbf{H b A}_{1 \mathbf{c}}(\mathrm{mg} / \mathrm{dl})$} & \multirow{2}{*}{$\mathbf{P}$} \\
\hline & $\begin{array}{c}5-7 \\
n=5\end{array}$ & $\begin{array}{c}7-9 \\
n=17\end{array}$ & $\begin{array}{c}9-11 \\
n=10\end{array}$ & $\begin{array}{c}11-\uparrow \\
n=13\end{array}$ & \\
\hline Epinephrine (\%) & $48.40 \pm 9.30$ & $46.29 \pm 3.04$ & $41.60 \pm 5.28$ & $44.23 \pm 4.48$ & $\mathrm{KW}=4.21 \mathrm{p}>0.05$ \\
\hline Collagen (\%) & $60.80 \pm 3.74$ & $52.88 \pm 3.98$ & $54.90 \pm 7.23$ & $55.00 \pm 5.96$ & $\mathrm{KW}=2.71 \mathrm{p}>0.05$ \\
\hline $\operatorname{ADP}(\%)$ & $72.80 \pm 4.1$ & $72.94 \pm 6.27$ & $68.10 \pm 9.74$ & $83.53 \pm 5.82$ & $\mathrm{KW}=4.21 \mathrm{p}>0.05$ \\
\hline
\end{tabular}

Table 6. Correlation between treatment type and platelet aggregation in the case group.

\begin{tabular}{lccc}
\hline \multicolumn{1}{c}{ case } & Oral Antidiabetic Drugs $\mathbf{n}=\mathbf{2 0}$ & Insulin $\mathbf{n}=\mathbf{2 5}$ & $\mathbf{p}$ \\
\hline Epinephrine (\%) & $47.70 \pm 3.23$ & $44.20 \pm 3.17$ & $\mathrm{p}=0.367 \mathrm{p}>0.05$ \\
Collagen (\%) & $56.90 \pm 4.35$ & $53.16 \pm 3.59$ & $\mathrm{p}=0.775 \mathrm{p}>0.05$ \\
ADP (\%) & $76.75 \pm 5.54$ & $73.44 \pm 4.84$ & $\mathrm{p}=0.698 \mathrm{p}>0.05$ \\
\hline
\end{tabular}

In this study, three different activators caused to three different aggregation responses and significantly increased aggregation response was predicted for only ADP. This may depend on the presence of different possible diabetic complications. Because, the presence of diabetic complications may cause to variations in the platelet agregations response. However, the diabetic complications were not examined in this study and we failed, therefore, to conduct an exact conclusion on this subject.

The finding of increased aggregation response by ADP in diabetic patients is in aggrement with the finding reported previously $[7,11,13,14]$. Altough it was reported previously that there was a possitive correlation between the age and platelet aggregation responses $[15,16]$. We failed to predicted such a correlation in this study. Knobler et al. [1] found no relationship between the platelet aggregation responces and the age of type $2 \mathrm{DM}$. Interestingly, we found a significant negative correlation between the platelet aggregation responses induced with epinephrine and diabetes duration. This finding suggest that there are possible new factors or mechanisms other than already known, having potence to interfere with platelet aggregation responses.

Mean platelet volume (MPV) is a marker of platelet function and activation. Larger platelets are more reactive and aggregable. Therefore it can be said that is a relationship between platelet function and diabetic complacations [17-20].

Increase in $\mathrm{HbA} 1 \mathrm{c}$ concentration, indicative of worsening glycemic control, was accompanied by increased mean platelet volume which reflects deterioration of platelet function [21]. Whereas Hekimsoy et al. [22] did not found any correlation between $\mathrm{HbAlc}$ and MPV.

We found no relationship between HbAlc levels and the platelet aggregation responses; in aggrement with the findings of Mandal et al. [23] and of Hughes et al. [24]. Konya et al. [25] was found ADP-induced platelet aggregate were significantly reduced in the group with improved $\mathrm{HbAlc}$.

The previous studies, except one [26], showed evidencies that oral antidiabetic drugs (OAD) have improving effects on platelet functions [27-30]. Another study was found that in the patients with improved glycemic control, gliclazide could inhibit ADP-induced platelet aggregation via the serotonin pathway [25]. Some studies suggests that insulin may inhibit platelet function at physiological concentrations $[31,32]$, but enhance platelet aggregation at supraphysiological concentrations [33,34]. However; Hu et al. [35] had found that even physiological concentrations of insulin enhance platelet activation both in healthy subjects and in type I diabetic patient.

In our study, we found no significant difference in platelet aggregation responses regarding to the treatment type; insulin or OAD.

In conclusion, our findings supported that there several abmormalities in the platelet aggregation responses in type $2 \mathrm{DM}$ patients and that the differences are not in correlation with control levels of blood glucose. The subject requires more detailed studies in the future. This findings suggest that there are possibly new factors or mechanisms having potence to interfere with there platelet aggregation responses.

\section{REFERENCES}

[1] Knobler, H., Savion, N., Shenkman, B., Kotev-Emeth, S. 
and Varon, D. (1998) Shear-induced platelet adhesion and aggregation on subendothelium are increased in diabetic patients. Thrombosis Research, 90(4), 181-190.

[2] Li, Y., Woo, V. and Bose, R. (2001) Platelet hyperactivity and abnormal $\mathrm{Ca}_{2+}$ homeasis in diabetes mellitus. American Journal of Physiol Heart Circ Physiol, 280(4), 1480-1489.

[3] Ross, R. (1986) The pathogenesis of atherosclerosis. The New England Journal of Medicine, 314(8), 488-500.

[4] Sinzinger, H. (1986) Role of platelets in atherosclerosis. Semin Thromb Haemostasis, 2(12), 124-133.

[5] Bern, M.M. (1978) Platelet functions in diabetes mellitus. Diabetes, 27(3), 342-350.

[6] Colwell, J.A., Lopes-Virella, M. and Halushka, P.V. (1981) Pathogenesis of atherosclerosis in diabetes mellitus. Diabetes Care, 4(1), 121-133.

[7] Vinik, A.I., Erbas, T., Park, T.S., Nolan, R. and Pittenger, G.L. (2001) Platelet Dysfunction in Type 2 Diabetes. Diabetes Care, 24(8), 1476-1485.

[8] Davi, G., Gresele, P., Violi, F., Basili, S., Catalano, M., Giammarresi, C., Volpato, R., Nenci, G. G., Ciabattoni, G. and Patrono, C. (1997) Diabetes mellitus, hypercholesterolemia, and hypertension but not vascular disease per se are associated with persistent platelet activation in vivo. Evidence derived from the study of peripheral arterial disease. Circulation, 96(1), 69-75.

[9] Colwell, J.A., Winocour, P.D. and Halushka, P.V. (1983) Do platelets have anything to do with diabetic microvascular disease? Diabetes, 32(2), 14-19.

[10] Natarajan, A., Zaman, A.G. and Sally, M.M. (2008) Platelet hyperactivity in type 2 diabetes: Role of antiplatelet agents. Diabetes and Vascular Disease Research, 5(2), 138-144.

[11] Tóth, L., Szénási, P., Jámbor, G., Kammerer, L. and Romics, L. (1992) Platelet Function in Male Diabetic With and Without Macrovascular Complications. Diabetes Res Clin Pract, 15(2), 143-148.

[12] Hajek, A.S. and Joist, J.H. (1992) Platelet insulin receptor. Methods Enzymol, 215, 399-403.

[13] Trovati, M., Anfossi, G., Cavalot, F., Massucco, P., Mularoni E. and Emanuelli, G. (1988) Insulin directly reduces platelet sensivity to aggregating agents. Diabetes, 37(6), 780-786.

[14] DeFronzo, R.A. (1992) Insulin resistance, hyperinsulinemia and coronary artery disease, a complex metabolic web. Journal of Cardiovascular Pharmacology, 20(11), $1-16$.

[15] Terres, W., Weber, K., Kupper, W. and Bleifeld, W. (1991) Age, cardiovascular risk factors and coronary heart disease as determinants of platelet function in men. A multivariate approach. Thrombosis Research, 62(6), 649661.

[16] O'Donnell, C.J., Larson, M.G., Feng, D., Sutherland, P. A., Lindpaintner, K., Myers R.H., D'Agostino, R.A., Levy, D. and Tofler, G.H. (2001) Genetic and Environmental Contributions to Platelet Aggregation: Framingham Heart Study. Circulation, 103(25), 3051-3056.

[17] Bath,, P.M. and Butterworth, R.J. (1996) Platelet size: Measurement, physiology and vascular disease. Blood Coagulation and Fibrinolysis, 7(2), 157-161.

[18] Kim, S.W., Ryu, G.H., Lee, I., Koh, J.J., Min, B.G. and Lee, H.K. (1995) Adhered platelet morphology in dia- betes mellitus. Diabetes and Metabolism, 21(1), 50-53.

[19] Mazzanfi, L. and Mutus, B. (1997) Diabetes-induced alterations in platelet metabolism. Clinical Biochemistry, 30(7), 509-515.

[20] Srivastava, S., Joshi, C.S., Sethi , P.P., Agrawal, A.K., Srivastava, S.K. and Seth, P.K. (1994) Altered platelet functions in non-insulin-dependent diabetes mellitus (NIDDM). Thrombosis Research, 76(5), 451-461.

[21] Demirtunc, R., Duman, D., Basar, M., Bilgi, M., Teomete, M. and Garip, T. (2009) The relationship between glycemic control and platelet activity in type 2 diabetes mellitus. Journal of Diabetes and its Complications, 23(2), 89-94.

[22] Hekimsoy, Z., Payzin, B., Ornek, T. and Kandoğan, G. (2004) Mean platelet volume in Type 2 diabetic patients. Journal of Diabetes and its Complications, 18(3), 173176.

[23] Mandal, S., Sarode, R., Dash, S. and Dash, R.J. (1993) Hyperaggregation of platelets detected by whole blood platelet aggregometry in newly diagnosed noninsulindependent diabetes mellitus. American Journal of Clinical Pathology, 100(2), 103-107.

[24] Hughes, A., McVerry, B.A., Wilkinson, L., Goldstone, A. H., Lewis, D. and Bloom, A. (1983) Diabetes, a hypercoagulable state? Hemostatic variables in newly diagnosed type 2 diabetic patients. Acta Haematol, 69(4), 254259.

[25] Konya, H., Hasegawa, Y., Hamaguchi, T., Satani, K., Umehara, A., Katsuno, T., Ishikawa, T., Miuchi, M., Kohri, K., Suehiro, A., Kakishita, E., Miyagawa, J.I. and Namba, M. (2010) Effects of gliclazide on platelet aggregation and the plasminogen activator inhibitor type 1 level in patients with type 2 diabetes mellitus. Metabolism, Epub ahead of print.

[26] Larkins, R.G., Jerums, G., Taft, J.L., Godfrey, H., Smith, I. L. and Martin, T.J. (1988) Lack of effect of gliclazide on platelet aggregation in insulin-treated and non-insulintreated diabetes: A two-year controlled study. Diabetes Research and Clinical Practice, 4(2), 81-87.

[27] Losert, V.W., Scholz, C. and Hoder, A. (1975) Mechanisms of platelet aggregation inhibition caused by sulfonylurea compounds. Arzneimittelforschung, 25(4), 547-560.

[28] Klaff, L.J., Vinik, A.I., Jackson, W.P., Malan, E., Kernoff, L. and Jacobs, P. (1979) Effects of the sulphonylurea drugs gliclazide and glibenclamide on blood glucose control and platelet function. South African Medical Journal, 56(7), 247-250.

[29] Siluk, D., Kaliszan, R., Haber, P., Petrusewicz, J., Brzozowski, Z. and Sut, G. (2002) Antiaggregatory activity of hypoglycaemic sulphonylureas. Diabetologia, 45(7), 1034-1037.

[30] Qi, R., Ozaki, Y., Satoh, K., Kurota, K., Asazuma, N., Yatomi, Y. and Kume S. (1995) Sulphonylurea agents inhibit platelet aggregation and $\left[\mathrm{Ca}_{2+}\right] \mathrm{i}$ elevation induced by arachidonic acid. Biochemical Pharmacology, 49(12), 1735-1739.

[31] Westerbacka, J., Yki-Järvinen, H., Turpeinen, A., Rissanen, A., Vehkavaara, S., Syrjälä, M. and Lassila, R. (2002) Inhibition of platelet-collagen interaction: An in vivo action of insulin abolished by insulin resistance in obesity. Arteriosclerosis, Thrombosis, and Vascular Biology, 22(1), 167-172. 
[32] Trovati, M. and Anfossi, G. (1998) Insulin, insulin resistance and platelet function: Similarities with insulin effects on cultured vascular smooth muscle cells. Diabetologia, 41(6), 609-622.

[33] Murer, E.H., Gyda, M.A. and Martinez, N.J. (1994) Insulin increases the aggregation response of human platelets to ADP. Thrombosis Research, 73(1), 69-74.

[34] Anfossi, G., Massucco, P., Mattiello, L., Piretto, V., Mular- oni, E., Cavalot, F., Paoletti, G. and Trovati, M. (1996) Insulin exerts opposite effects on platelet function at physiological and supraphysiological concentrations. Thrombosis Research, 82(1), 57-68.

[35] Hu, H., Hjemdahl, P. and Li, N. (2002) Effects of insulin on platelet and leukocyte activity in whole blood. Thrombosis Research, 107(5), 209-215. 